\title{
PENGARUH KEPEMIMPINAN TRANSFORMASIONAL KEPALA SEKOLAH, MOTIVASI KERJA, DAN KEDISIPLINAN TERHADAP PENGEMBANGAN KARIR GURU SD
}

\author{
Ngadimin, Wuradji \\ SDN Ngrenak, Universitas Negeri Yogyakarta \\ suprafit237@yahoo.co.id
}

\begin{abstract}
Abstrak
Penelitian ini bertujuan untuk mengungkapkan besarnya pengaruh kepemimpinan transformasional kepala sekolah, ditinjau dari persepsi guru, motivasi kerja guru dan kedisiplinan guru terhadap pengembangan karir guru SD se kecamatan Godean Kabupaten Sleman. Penelitian ini merupakan penelitian pendekatan kuantitatif jenis non eksperimental, yang terdiri atas tahap perencanaan dan penyusunan proposal, validasi instrumen, uji coba instrumen, pengambilan data penelitian, pengolahan hasil data dari lapangan dan penyusunan laporan hasil penelitian. Subjek penelitian ini adalah guru-guru di lingkungan UPT Yandik kecamatan Godean, guru yang terlibat dalam penelitian ini adalah 198 otrang. Hasil penelitian deskriptif mengungkapkan bahwa kepemimpinan transformasional kepala sekolah berada pada posisi kategori tinggi dengan rata-rata 3,44; motivasi kerja guru 3,20; kedisiplinan guru 3,34 dan pengembangan karir guru adalah 2,94. Hasil penelitian secara parsial menunjukkan bahwa kepemimpinan transformasional kepala sekolah memberi pengaruh signifikan 18,1\% (adjusted $\mathrm{r}^{2}$ $=18,1)$ dan $(\mathrm{p}<0,05)$ terhadap pengembangan karir, motivasi kerja guru memberi pengaruh signifikan sebesar $7,9 \%$ (adjusted $\left.\mathrm{r}^{2}=0,079\right)$ dan $(\mathrm{p}<0,05)$, terhadap pengembangan karir, dan kedisiplinan guru berpengaruh signifikan sebesar 8,2\% (adjusted $\left.\mathrm{r}^{2}=0,082\right)$ dan $(\mathrm{p}<0,05)$, terhadap pengembangan karir guru sekolah dasar. Kepemimpinan transformasional kepala sekolah, motivasi kerja guru dan kedisiplinan guru berpengaruh signifikan sebesar 24,8\% (adjusted $\mathrm{R}^{2}$ ) sebesar 0,248 dengan $\mathrm{F} 19,955(\mathrm{p}<0,05)$ terhadap pengembangan karir guru SD seKecamatan Godean, Kabupaten Sleman, Daerah Istimewa Yogyakarta.
\end{abstract}

Kata kunci: kepemimpinan transformasional kepala sekolah, motivasi kerja guru, kedisiplinan guru dan pengembangan karir guru.

\section{THE EFFECTS OF PRINCIPAL'S TRANSFORMATIONAL LEADERSHIP, WORKS MOTIVATION, AND DISCIPLINE ON THE CAREER DEVELOPMENT OF ELEMENTARY SHOOL TEACHERS}

\begin{abstract}
This study aims to investigate the extent of the effects of principals' transformational leadership in terms of teachers' perception, work motivation, and discipline on the career development of elementary school teachers in Godean District, Sleman Regency. This research is a type of non-experimental quantitative approach, The subjects were teachers in the Unit Yandik Godean districts, teachers involved in the study were 173 persons. The descriptive results of the study show that principals' transformational leadership is in the high category with a mean of 3.44 , teachers' work motivation is 3.46, teachers' discipline is 3.36, and teachers' career development is 2.94. The results of the regression analysis show that principals' transformational leadership has a significant effect of $18,1 \%(p<0.05)$ on elementary school teachers' career development, teachers' work motivation has a significant effect of $7,9 \% \quad(p<0.05)$ on elementary school teachers' career development, and teachers' discipline has a significant effect of $8,4 \% \quad(p<0.05)$ on elementary school teachers' career development. The results of the analysis show that principals' transformational leadership, teachers' work motivation, and teachers' discipline as an aggregate have a significant positive effect of 24,8\%, indicated by the statistical test showing $F=19,955(p<0.05)$, on the career development of elementary school teachers in Godean District, Sleman Regency, Yogyakarta Special Territory.
\end{abstract}

Keywords: principals' transformational leadership, teachers' work motivation, teachers' discipline, teachers' career development 


\section{Pendahuluan}

Pendidikan merupakan bentuk investasi jangka panjang bagi bangsa Indonesia. Setiap anak bangsa ini wajib menempuh pendidikan dasar. Pendidikan dasar ini gratis diselenggarakan oleh negara baik untuk anak laki-laki maupun anak perempuan. Program wajib belajar pendidikan dasar 9 tahun ini terdiri dari Sekolah Dasar 6 tahun dan Sekolah Menengah Pertama 3 tahun. Pelaksanaan program pendidikan di Indonesia menurut Undang-Undang Nomor: 2 tahun 2003 tentang Sistem Pendidikan Nasional bertujuan untuk mengem bangkan potensi peserta didik agar menjadi manusia yang beriman dan bertaqwa kepada Tuhan Yang Maha Esa, berakhlak mulia, sehat, berilmu, cakap, kreatif, mandiri, dan menjadi warga negara yang demokratis serta bertanggung-jawab.

Pendidikan di Indonesia dimulai dari Taman Kanak-kanak/Pendidikan Usia Dini hingga Perguruan Tinggi. Pendidikan dilaksana kan oleh pemerintah dan oleh swasta. Seluruh wilayah Negara Kesatuan Republik Indonesia sekarang sudah terjangkau layanan Pendidikan Dasar. Taman Kanak-Kanak bukan merupakan wajib bagi anak yang akan memasuki Sekolah Dasar. Yang menjadi syarat utama masuk ke Sekolah Dasar adalah usia anak. Setiap anak yang berusia diatas 7 tahun atau lebih wajib diterima di Sekolah Dasar, sedangkan yang berusia kurang dari 7 tahun dapat diterima apabila daya tampung sekolah mampu. Setiap anak yang akan mengikuti pendidikan di SMP ia wajib menamatkan pendidikan di Sekolah Dasar, begitu pula bagi mereka yang akan melanjutkan ke SMA ia juga harus menamatkan pendidikan di SMP. Sebagai dasar pertimbangan untuk masuk ke sekolah tingkat di atasnya adalah nilai prestasi siswa.

Peningkatan mutu pendidikan dewasa ini merupakan suatu kebutuhan yang tidak dapat ditunda-tunda lagi. Keberhasilan pembangunan suatu bangsa terutama ditentukan oleh keberadaan sumber daya manusia berkualitas, yang hanya dapat dihasilkan lewat pendidikan yang berkualitas pula. Pengalaman pembangun- an di negara-negara Asia seperti Jepang, Taiwan, Korea merupakan bukti yang sangat meyakinkan bahwa sumber daya manusia memegang peranan yang sangat menentukan dalam bidang pembangunan suatu bangsa.

Peranan guru dalam meningkatkan kualitas pendidikan sangat dominan. Guru harus mampu merencanakan program, melaksanakan program, dan mengevaluasi program pembelajaran dengan baik. Guru harus mampu membangkitkan motivasi kepada siswa untuk rajin belajar dengan tertib, teratur, dan terarah. Guru harus mem berikan pelayanan terbaik kepada anak didiknya, memberikan fasilitas. Agar dapat memberikan pelayanan yang prima kepada anak didiknya guru harus mendapatkan kesejahteraan yang cukup, kenyamanan dalam bekerja, dan mendapatkan kesempatan meningkatkan kemampuan profesionali tasnya. Terselenggaranya pendidikan yang berkualitas, baik, tertib, dan lancar memerlukan tenaga administrasi yang mampu melaksanakan tugas dengan baik, berdisiplin, dan bertanggung jawab. Tenaga kependidikan yang ada di sekolah harus mendapatkan perhatian agar motivasinya tetap tinggi sehingga membe rikan pelaya-nan yang prima kepada anak didiknya.

Prestasi anak dibidang akademik sangat menjadi perhatian masyarakat. Bahkan asumsi yang berkembang adalah tolok ukur baik dan buruknya sekolah sangat ditentukan oleh perolehan Nilai Ujian Nasional. Hal ini menye babkan sekolah harus selalu berusaha mening katkan prestasi belajar siswa. Ada berbagai cara yang dapat dilakukan sekolah dan jajarannya untuk meningkatkan prestasi belajar siswa, ada yang dengan menyelenggarakan kegiatan ekstra diluar jam pelajaran rutin, dalam bentuk less atau privat.

Menurut Marfuah sebagai Kepala Unit Pelaksana Teknis Pelayanan Pendi dikan Kecamatan Godean, bahwa prestasi belajar siswa masih belum sesuai dengan harapan. Dari data yang ada menunjukkan rata-rata nilai Ujian Nasional adalah 6,34 untuk pelajaran Bahasa Indonesia, Mate- 
matika 5,25 dan 6,78 untuk Ilmu Pengetahuan Alam. Ada beberapa faktor yang mempengaruhi prestasi belajar siswa, yaitu faktor jasmani, faktor psikologis, dan faktor kelelahan. Faktor jasmani terdiri dari faktor kesehatan dan cacat tubuh. Faktor psikologis terdiri dari intelegensi, perhatian, bakat, minat, motivasi, kematangan, dan kesiapan. Faktor kelelahan karena aktifitas kegiatan fisik yang berlebihan. Di samping itu keberhasilan siswa memperoleh prestasi yang tinggi juga berkat bimbingan dari kepala sekolah, guru, dan peranan orang tuaUntuk mencapai tujuan pendidikan nasional kita, harus melaksanakan dengan disi plin yang tinggi. Kedisplinan harus dilaksanakan oleh semua pihak yang terlibat dalam proses pencapaian tujuan pendidikan, baik oleh kepala sekolah, guru, maupun oleh siswa. Kedisiplinan di suatu instansi akan sangat tergantung dari berbagai faktor antara lain faktor kepemimpinan kepala instansi, faktor motivasi kerja, faktor kompensasi, kepuasan kerja guru suasana kerja, dan lingkungan kerja. Untuk mencapai hasil yang maksimal semua harus melaksanakan tugas dengan baik sesuai dengan bidang tugas masing-masing

Menurut Marfuah sebagai Kepala Unit Pelaksana Teknis Pelayanan Pendidi kan Kecamatan Godean, bahwa prestasi belajar siswa masih belum sesuai dengan harapan. Dari data yang ada menunjukkan rata-rata nilai Ujian Nasional adalah 6,34 untuk pelajaran Bahasa Indonesia, Matema tika 5,25 dan 6,78 untuk Ilmu Pengetahuan Alam. Ada beberapa faktor yang mempengaruhi prestasi belajar siswa, yaitu faktor jasmani, faktor psikologis, dan faktor kelela han. Faktor jasmani terdiri dari faktor kesehatan dan cacat tubuh. Faktor psikolo gis terdiri dari intelegensi, perhatian, bakat, minat, motivasi, kematangan, dan kesiapan. Faktor kelelahan karena aktifitas kegiatan fisik yang berlebihan. Di samping itu keber hasilan siswa memperoleh prestasi yang tinggi juga berkat bimbingan dari kepala sekolah, guru, dan peranan orang tua.
Kepemimpinan kepala sekolah adalah sangat menentukan. Pemimpin adalah ibarat sebuah pilot dalam suatu penerbangan, nahkoda dalam sebuah kapal laut, sopir dalam sebuah kendaraan. Seorang pemimpin harus dapat membawa dengan selamat penumpangnya untuk mencapai tujuan. Sebuah organisasi akan berhasil atau gagal sebagian besar ditentukan oleh kepemim pinan. Demikian juga, keberhasilan sekolah adalah keberhasilan kepala sekolah karena kepala sekolah memiliki kekuatan sentral yang menjadi penggerak dan pengendali kehidupan sekolah. Pengembangan karir merupakan peningkatan kemampuan dan kompetensi guru untuk melaksanakan tugas dalam proses belajar dan mengajar. Pengem bangan ini harus dilakukan secara terus menerus oleh guru dan didukung oleh kepa la sekolah dan instansi di atasnya. Pening katan kemampuan dan kompetensi guru diharapkan agar guru dapat bertindak dan bertingkah laku secara profesional.

Motivasi merupakan dorongan dari dalam individu untuk melakukan sesuatu. Seorang guru akan bekerja dengan giat apabila ia mempunyai motivasi yang tinggi untuk mencapai tujuan. Tugas utama guru adalah mendidik dan mengajar anak didik nya. Motivasi dapat timbul dari dalam individu ataupun dari luar individu. Motivasi dari dalam disebut motif instrinsik yang meliputi keyakinan, harapan, minat, keyakinan dan lain-lain, sedangkan motif yang berasal dari luar misalnya ingin mendapatkan penghar gaan, mencukupi kebutuhan, dan lain-lain. Seseorang yang bekerja dengan motivasi yang rendah ia akan kurang bersemangat, dan akan menunjukkan kinerja yang kurang memuaskan.

Stogdill (Nwaogu, 2014, p.5) menya takan "leadership is the processes of influencing group activities toward goal setting and goal achievment", kepemim pinan adalah proses mempengaruhi aktifitas kelompok untuk menetapkan tujuan dan untuk mencapai tujuan yang telah ditetapkan. Pada prinsipnya menurut Stogdill kepemimpinan ditujukan untuk mencapai tujuan 
baik secara kelompok dalam suatu organisasi atau secara perseorangan. Tujuan ini merupakan tujuan akhir yang akan dicapai oleh suatu organisasi.

Kepemimpinan dalam suatu organisa si adalah sangat penting. Pemimpin adalah ibarat sebuah pilot dalam suatu penerbang an, nahkoda dalam sebuah kapal laut, sopir dalam sebuah kendaraan. Seorang pemimpin harus dapat membawa dengan selamat penumpangnya untuk mencapai tujuan. Sebuah organisasi Toha, (2006, p.1) akan berhasil atau gagal sebagian besar ditentu kan oleh kepemimpinan.

Robbins (1996, p.39) mendefinisikan kepemimpinan sebagai "kemampuan untuk mempengaruhi suatu kelompok ke arah tercapainya suatu tujuan". Sumber pengaruh ini bisa bersifat formal, seperti misalnya yang disediakan oleh pemilikan peringkat manajerial dalam suatu organisasi. Karena posisi manajemen muncul bersama suatu tingkat wewenang yang ditunjuk secara formal, seorang pejabat menjalankan suatu peran kepemimpinan semata-mata karena kedudukannya dalam suatu organisasi.

Sutisna (1993, p.255) menyatakan bahwa, "kepemimpinan adalah kemampuan membujuk orang lain supaya mengejar tujuan-tujuan yang telah ditetapkan dengan bergairah". Yukl (2002, p.2) menyatakan bahwa: Most definition of leadership reflect the assumption that involves a social involves a process where by intentional influence is exerted by one person over other peaple to guide, structure and facilitateies activities and relationship in group or organization.

Yukl (2002: p.2) menyatakan bahwa Most definition of leadership reflect the assumption that involves a social involves a process where by intentional influence is exerted by one person over other peaple to guide, structure and facilitateies activities and relationship in group or organization.

Bahasa Indonesia dari petikan tersebut kurang lebih adalah kebanyakan definisi kepemimpian merefleksikan suatu asumsi bahwa kepemimpinan itu melibatkan sebuah proses, pengaruh sosial yang pengaruh itu sengaja digunakan seseorang kepada orang lain untuk membangun aktivitas dan hubungan harmonis dalam kelompok atau organisasi.

Hersey \& Blanchard (1982, p.83) menjelaskan bahwa, kepemimpinan "is the process of influenting the activities of an individual or group in efforts toward goal achievement in a given situation". Dari pengertian tersebut dapat diartikan bahwa studi tentang kepemimpinan bukanlah terletak pada orangnya, melainkan pada bagaimana proses orang tersebut dalam mempengaru hi orang lain baik secara individual maupun secara kelompok dalam situasi tertentu, sehingga orang yang dipengaruhi tersebut dapat melakukan apa-apa yang diinginkan oleh yang mempengaruhi.

Hoy \& Miskel (2008, pp.420-421) menjelaskan kepemimpinan sebagai berikut ini "Leadership should be defined broadly as a social process in which a member or mem bers of a group or organization influence the inpretation of internal and external events, the choice of goals or desired out comes, organizations of work activities, individual motivation and abilities, power relations an shared orientation".

Sadler (Wuradji, 2008, p. 48) menya takan bahwa, "transformational leadership is the procces of engaging the commitment of employees in the context of share values and share vision". Kepemimpinan transformasional adalah suatu proses kepemimpinan dimana pemimpin mengem bangkan komit men pengikutnya dengan berbagi nilainilai dan berbagi visi organisasi.

Setiawan \& Muhith (2013, p.98) menyatakan bahwa: Kepemimpinan transformasional sebuah proses di mana pemim pin mengambil sebuah tindakan-tindakan untuk meningkatkan kesadaran rekan kerja mereka tentang apa yang benar dan apa yang penting, untuk meningkatkan kemata ngan motivasi rekan kerja mereka serta mendorong mereka untuk mencapai kemaslahatan kelompok, organisasi, atau masyarakat.

Bass \& Reggio (2005, p.6) menjelaskan bahwa komponen kepemimpinan transformasional terdiri atas: (a) ideal in- 
fluence (II). Transformational leaders have in ways that allow them to serve as role models for there followers. The leaders are amired, respect, and trusted. Follower identify with the leaders and want to emulate them; (b) inpirational motivation (IM). Transfor mational leaders be have in ways that motivate and inspire those around them by providing meaning and chalengge to their followers work; (c) intellectual stimulation (IS). Transfor mational leaders stimulate there followers efforts to be innovative and creative by questioning assumptions, reframing problem, and approchingold stimulations in new ways; (d) individual concideration (IC). Transfor mational leaders pay special attentionto each individual followers need for achievment and growth by acting as a coach or mentor. Followers and coleaguen are developed to successively higher level of potential.

Berikut ini disampaikan ciri-ciri kepemimpinan kepala sekolah transformasional menurut Wuradji (2009, p.52): (1) memiliki keberanian untuk melakukan perubahan menuju tingkat produktifitas yang lebih tinggi; (2) mampu membangkitkan semangat dan motivasi pengikutnya untuk bekerja keras, (3) mampu mengembangkan semangat kebersamaan, disiplin dan motivasi untuk maju; (4) mampu mengembangkan kesadaran berorganisasi; (5) mampu memberikan perlindungan terhadap bawahan; (6) mampu menampung dan menangkap aspirasi bawahan; (7) memperjuangkan kepentingan pengikut; (8) pengikut selalu memuja akan kemam puan pemimpinnya; (9) kepala sekolah sebagai agen perubahan; (10) selalu belajar sepanjang hayat (they are life long leaner); (11) mampu memecahkan masalah yang kompleks, memiliki rasa percaya diri yang kuat dalam menanggung resiko atas keputusan yang diambilnya.

Pengertian kepala sekolah menurut Wahjosumidjo (2011, p.83) adalah "seorang tenaga fungsional guru yang diberi tugas untuk memimpin suatu sekolah, di mana diselenggarakannya proses belajar mengajar atau tempat di mana terjadi interaksi antara guru yang memberi pelajaran dan murid yang menerima pelajaran". Makna kata memimpin dalam rumusan di atas mengandung makna luas, yaitu kemampuan untuk menggerakkan segala sumber yang ada pada suatu sekolah (madrasah) sehingga dapat didayagunakan secara maksimal untuk mencapai tujuan yang telah ditetapkan. Di lapangan memimpin memiliki konotasi makna menggerakkan, mengarahkan, mem bimbing, melindungi, membina, memberi kan teladan, memberikan dorongan, mem berikan bantuan, dan lain lain.

Sebagai pendidik, kepala sekolah harus senantiasa berupaya meningkatkan kualitas pembelajaran yang dilakukan oleh para guru. Dalam hal ini faktor pengalaman akan sangat mempengaruhi profesionalisme kepala sekolah, terutama dalam mendukung terbentuknya pemahaman tenaga kependidikan terhadap pelaksanaan tugasnya. Pengalaman semasa menjadi guru sangat mempengaruhi kemampuan kepala sekolah dalam melaksanakan tugasnya.

Usaha-usaha yang dapat dilakukan kepala sekolah dalam meningkatkan kinerjanya sebagai seorang pendidik khususnya dalam meningkatkan kinerja tenaga kependidikan dan prestasi belajar peserta didik adalah sebagai berikut ini: (1) mengikut sertakan para guru dalam penataran-penataran, menambah wawasan para guru, mendorong untuk belajar ke jenjang yang lebih tinggi, (2) kepala sekolah harus menggerakkan team evaluasi hasil belajar peserta didik untuk lebih giat belajar, (3) menggunakan waktu belajar secara efektif di sekolah

Kepala sekolah juga berperan sebagai seorang supervisor. Supervisi yang dilakukan kepala sekolah adalah untuk mengawasi pelaksanaan proses belajar dan mengajar di sekolah yang ia pimpin. Tujuan pelaksanaan supervisi yang dilaksanakan adalah agar seluruh aktifitas kegiatan sekolah bermuara pada pencapaian tujuan yang telah ditetapkan secara efektif dan efisien. Sedangkan yang dimaksud supervisi menurut Sergiovani \& Starrat (Nurtain, 1739, p.14) menyatakan bahwa: 
Secara tradisional, supervisi dipan dang sebagai daerah orang yang bertanggung jawab terhadap perbaikan pengajaran. Walaupun kita berpegang pada pandangan ini. Kita dapat menambahkan titik berat tanggung jawab pengajaran pada semua tujuan umum sekolah yang dapat dicapai melalui atau tergantung pada organisasi yang manusiawi di sekolah.

Menurut Gerungan (2010, pp.154155) motif dapat dibedakan menjadi 3 macam, yaitu (1) motif biogenetis, yaitu motif yang berasal dari kebutuhan-kebutuhan organisme demi kelangsung an hidupnya (2) motif sosiogenetis yaitu motif yang berkembang berasal dari lingkungan kebudayaan tempat orang tersebut berada. (3) motif teologis dalam motif ini manusia sebagai mak hluk yang berkebutuhan, sehingga ada interaksi antara manusia dengan Tuhan-Nya

Mulyasa (2004, p.126) menjelaskan bahwa kepemimpinan kepala sekolah berperan sebagai motor penggerak sekali gus penentu arah kebijakan sekolah yang akan menentukan cara pencapaian tujuan-tujuan sekolah dan pendidikan. Un tuk mencapai efektifitas dalam kepemim pinannya, kepala sekolah harus memiliki tiga keterampilan konseptual berkaitan dengan keterampilan untuk memahami dan mengoperasikan organisasi. Keterampilan manusiawi berkaitan dengan keterampilan bekerja sama, memotivasi dan memimpin. Keterampilan teknis berkaitan dengan keterampilan dalam menggunakan pengetahuan, metode, teknik, dan perlengkapan untuk menyele saikan tugas tertentu

Nawawi (1995, p.9) menjelaskan bahwa, "kepemimpinan kemampuan atau kecerdasan mendorong sejumlah orang (dua orang atau lebih) agar bekerjasama dalam melaksa nakan kegiatan-kegiatan yang tera rah pada satu tujuan bersama". Pengertian tersebut dapat dipahami bahwa kepemim pinan pendidikan adalah segenap kegiatan dalam usaha mempengaruhi personil di lingkungan pendidikan pada situasi tertentu agar melalui kerjasama mau bekerja dengan penuh tanggung jawab dan ikhlas demi tercapainya tujuan pendidikan yang telah ditentukan.

Dirawat (Permadi \& Arifin, 2010, p.45) lebih jauh menjelaskan bahwa "kepemimpinan pendidikan sebagai suatu kemampuan dalam proses mempe ngaruhi, mengkoordinir, menggerakkan orang lain yang ada hubungannya deng an pengembangan ilmu pendidikan dan pelaksanaan pendidikan dan pengajaran agar supaya kegiatan-kegiatan yang dijalankan dapat lebih efektif dan efisien di dalam pencapaian tujuan pendidikan dan pengajaran".

Wahjosumidjo (2011, p.122) menge mukakan bahwa, "memahami arti pendidik tidak cukup berpegang pada konotasi yang terkandung dalam definisi pendidik, melainkan harus dipelajari keterkaitannya dengan makna pendidikan, sarana dan prasarana, bagaimana strategi pendidikan itu dilaksanakan". Untuk kepentingan tersebut, kepala sekolah harus berusaha menanam kan, memajukan, dan meningkatkan sedikit nya 4 macam nilai, yakni pembinaan mental, moral, fisik, dan artistik.

Menurut Gomes (Sulistyani, 2011, pp.323-324) ada beberapa faktor yang mempengaruhi produktifitas pegawai yaitu: (1) usaha, (2) motivasi, (3) kemampuan, (4) kesempatan dan kejelasan tujuan.

Menurut Pasolong (2010, p.152) ada 2 faktor yang mempengaruhi motivasi yaitu: (1) Faktor ekstern. yang meliputi kepemimpinan, lingkungan kerja yang menyenangkan, kompisisi yang memadahi, adanya penghargaan atas prestasi, status dan tanggung jawab dan peraturan yang berlaku. (2) Faktor intern. Yang meliputi kematangan pribadi, tingkat pendidikan, keinginan dan harapan pribadi, kebutuhan terpenuhi, kelelaan dan kebosanan dan kepuasan kerja.

Disiplin menurut Siagian (2008, pp. 305-307) adalah, "merupakan tindakan manajemen untuk mendorong anggota organisasi memenuhi tuntutan berbagai ketentuan tersebut. Mangkunegara (2011, pp. 129-130) mengungkapkan bahwa, ada 2 bentuk disiplin kerja yaitu: (1) disiplin preventif adalah suatu upaya menggerakkan pegawai mengikuti dan mematuhi pedo- 
man kerja aturan yang telah digariskan oleh perusahaan. (2) disiplin korektif, merupakan suatu upaya menggerakkan pegawai menyatukan suatu peraturan dan mengarah kan untuk tetap mematuhi peraturan sesuai dengan pedoman yang berlaku pada peru sahaan

Menurut Danim (2012, p.138) menje laskan bahwa, "kedisiplinan diri berkaitan dengan ketaatasasan yang meliputi: (1) tepat waktu, (2) taat asas atau janji, (3) mengikuti prosedur standar, (4) bekerja atas dasar stan dar mutu, (5) bekerja sesuai dengan standar hasil, (6) tepat sasaran, (7) tidak melanggar aturan, (8) tidak melakukan sesuatu yang dilarang pada tempattempat tertentu

Definisi perencanaan karir menurut Ardana, Mujiati, \& Utama (2012, p.117) adalah "keputusan yang diambil sekarang tentang hal-hal yang akan dikerjakan pada depan, Hasibuan (2003, p.68) menjelaskan bahwa, "pengembangan adalah suatu usaha untuk mengembangkan teknis, teoritis, konseptual, dan moral karyawan sesuai dengan kebutuhan pekerjaan jabatan mela lui pendidikan dan latihan". Pendidi kan meningkatkan teoritis, konseptual, dan moral karyawan, sedangkan latihan bertu juan meningkatkan keterampilan teknis untuk pelaksanaan pekerjaan karyawan.

Menurut Flippo (1976, pp.211-212) pendidikan sebagai "Education is con cerned with increasing general knowledge and understanding of our total environ ment. Training is the act of increasing the knowledge and skill of an employee for doing a particular jo"

Sedangkan Sikula (1976, pp.227-228) menjelaskan "Development, in reference to staffing and personal matters, is a long term educational process utilizing a systematic and organized procedur by which manajerial personal learn coceptual ang theoritical knowledge for general purposes (Steinmetz). Trainning is short term educational process utilizing a systematic and organized procedure by which nonmanajerial personel learn technical knowledge and skill for a definite purpose".

Menurut Dubrin (Mangkunegara, 2011, p.77) mengemukakan bahwa Career Development, from the standpoint of the organization, is personnel activity which helps individuals plan their future career within the interprice, in order to help the enterprice achiece and the employee achieve macimum selfdevelopment.

Menurut Handoko (1991, p.121), "karir adalah semua pekerjaan (jabatan) yang dipunyai (dipegang) selama kehidupan kerja seseorang". Bagi banyak orang, pekerjaan-pekerjaan tersebut merupakan suatu bagian dari rencana yang disusun secara hati-hati. Menurut Malthis \& Jackson (2006, p.342) karir adalah "serang kaian posisi yang berkaitan dengan kerja yang ditempati sepanjang hidupnya".

Tujuan pengembangan karir menurut Dubrin (Mangkunegara, 2011, p.77) adalah: (a) to aid in achieving individual and organizational goals, (b) to indicated concern for the walfare of individuals, (c) to help individuals realizing the potentials, (d) to strengthen the relationship between the individuals and organization, (e) to demonstrate social responsibility, (f) to aid affirmative action (EEO), $(g)$ to reduce turnover personnel costs, $h$ ) to reduce manajerial and profesional absolescence, i) to encourage the long rang point of view.

Menurut Ivancevich (2010, p.437) terdapat 4 tingkatan karir (career stage) yatu apprenticeship, advancement, mainte nance dan strategic thinking Menurut Ardana, Mujiati, \& Utama (2012, pp.121-122) ada beberapa tahap perkembangan karir manusia. Tahap perkembangan, tahap eksplorasi, tahap pemantatapan, tahap pemeliharaan, dan tahap kemunduran.

\section{Metode Penelitian}

Jenis penelitian ini adalah penelitian expost fakto pendekatan kuantitatif jenis non eksperimental, dengan variabel $X_{1}$ adalah kepemimpinan transformasional kepala sekolah, $X_{2}$ adalah motivasi kerja guru, $X_{3}$ adalah kedisiplinan guru dan $Y$ adalah pengembangan karir guru sekolah dasar

Penelitian ini akan berusaha menemukan pengaruh antara variabel bebas (independent) dan variabel terikat (dependent) baik secara sendiri-sendiri (partial) atau bersama-sama. 
Tempat penelitian dilaksanakan di wilayah kecamatan Godean kabupaten Sleman Daerah Istimewa Yogyakarta. Sampel pada penelitian ini adalah guru SD se kecamatan Godean, dengan subjek yang diteliti adalah kepemimpinan transformasonal kepala sekolah, motivasi kerja guru, kedisiplinan guru terhadap pengembangan karir guru.

Populasi dalam penelitian ini adalah seluruh guru Sekolah Dasar di wilayah Kecamatan Godean, Kabupaten Sleman, Daerah Istimewa Yogyakarta, sebanyak 33 (tiga puluh tiga) sekolah.

Pengambilan sampel menggunakan teknik pengambilan secara acak (simple random sampling) adalah teknik pengambi lan sampel yang memberikan peluang yang sama bagi setiap unsur (anggota) populasi untuk dipilih menjadi anggota sampel, Sugiono (2011, p. 122).

Penghitungan jumlah sampel dipergunakan rumus Krejcie \& Morgan (Setiawan 2007, p.9). Penentuan jumlah sampel deng an melihat daftar yang terdapat dalam tabel Krejcie dan Morgan. Besarnya populasi penelitian ini adalah 471 maka dengan derajat kepercayaan $10 \%$ atau 0,01 , maka sampel yang diketemukan adalah 173 orang.

Arikunto (2010, p.115) menyatakan bahwa, "untuk penelitian ilmu pendidikan digunakan taraf signifikansi 0,05 atau 0,01, sedangkan untuk penelitian obat-obatan yang resikonya menyangkut jiwa manusia, diambil 0,005 atau 0,001 bahkan mungkin $0,0001 "$.

Subjek penelitian ini adalah guruguru di Wilayah UPT. Yandik Kecamatan Godean, masing-masing sekolah guru kelas $1,2,3,4,5$, dan 6 . Guru yang dijadi kan sampel berjumlah 173 orang

Variabel kepemimpinan transformasi onal kepala sekolah yang di teliti adalah meliputi unsur kharisma pemimpin, inspiration, intellectual stimulation, dan individual stimulation. Variabel motivasi kerja guru meliputi tingkat kemampuan guru, tang gungjawab dan keberanian guru menang gung resiko. Variabel motivasi kerja guru meliputi ketaatan guru pada peraturan yang berlaku, pelaksanaan tugas-tugas guru, tingkat kepemilikan etos kerja dan variabel pengembangan karir guru meliputi perkembangan karir guru, mutasi kerja guru dan promosi guru ke jabatan yang lebih tinggi.

Teknik pengumpulan data dari responden (guru) adalah dengan menggunakan kuesioner skala likerts dengan 4 alternatif jawaban, yaitu: (1) (sangat tidak setuju); (2) (ragu-ragu); (3) (setuju) dan (4) (sangat setuju). Setelah data terkumpul kemudian diolah dengan mengggunakan software SPSS for windows versi 16.

Kuesioner sebelum digunakan untuk penelitian terlebih dahulu disahkan oleh validator ahli bidang penelitian. Kuesioner yang sah menurut ahli kemudian di uji coba di lapangan. Uji coba paenelitian ini memilih lokasoi di kecamatan Minggir, kabupaten Sleman yang mempunyai kesa maan prestasi dengan kecamatan Godean.

Hasil uji coba instrumen di kecama tan Minggir menunjukkan bahwa variabel kepemimpinan transformasional kepala sekolah ada satu item yang tidak valid, variabel motivasi kerja guru satu variabel tidak valid sedangkan variabel kedisiplinan guru dan pengembangan karir guru semua valid. Penen tuan valid atau tidak ditentukan dengan menggu nakan SPSS versi 16 kemudian di bandingkan dengan tabel. Jika $r$ hitung lebih besar dari pada $r$ hitung maka instrumen itu valid untuk penelitian.

Pengujian instrumen juga dilihat dari taraf reliabilitas instrumen tersebut. Penen tuan taraf ini juga dilakukan dengan menggunakan SPSS adapaun hasilnya adalah sebagai berikut ini.

Tabel 1. Reliabilitas Instrumen

\begin{tabular}{lccc}
\hline \multicolumn{1}{c}{ Variabel } & $\begin{array}{c}\text { Koef. } \\
\text { Alpha }\end{array}$ & $\begin{array}{c}\text { Koef. } \\
\text { Kritis }\end{array}$ & Status \\
\hline $\begin{array}{l}\text { Kepemimpinan } \\
\text { transformasional } \\
\text { kepala sekolah }\end{array}$ & 0,915 & 0,6 & Valid \\
$\begin{array}{l}\text { Motivasi kerja guru } \\
\text { Kedisiplinan guru }\end{array}$ & 0,783 & 0,6 & Valid \\
$\begin{array}{l}\text { Pengembangan } \\
\text { karir guru }\end{array}$ & 0,837 & 0,6 & Valid \\
\hline
\end{tabular}


Data tersebut menunjukkan bahwa semua koefisien alpha dari variabel yang ada lebih besar dari koefisien kritis, yang berarti semua variabel adalah reliabel/ valid untuk mengadakan penelitian yang sebenarnya.

\section{Hasil Penelitian dan Pembahasan}

Penelitian ini merupakan studi kasus di Kecamatan Godean, Kabupaten Sleman, Daerah Istimewa Yogyakarta. Kecamatan Godean merupakan wilayah barat dari Kabupaten Sleman, sebelah barat berbatasan dengan Kecamatan Moyudan dan Kecamatan Minggir, sebelah utara berbatasan dengan Kecamatan Seyegan dan Kecamatan Mlati, sebelah timur berbatasan dengan Kecamatan Gamping, sebelah selatan berbatasan dengan Kecamatan Argomulyo Kabupa ten Bantul.

Pada penelitian ini disebarkan angket sebanyak 200 eksemplar, yang ditujukan ke semua sekolah negeri maupun swasta. Dari angket yang terkumpul sebanyak 173 eksemplar yang berasal dari 33 sekolah. Penyebab dari dua kuesioner yang tidak terkumpul adalah karena sesuai dengan kesepakatan waktunya belum jadi (belum diisi) oleh responden dan karena kuesioner hilang.

Tabel 2.

\begin{tabular}{|c|c|c|c|c|}
\hline $\begin{array}{l}\text { Variabel } \\
\text { penelitian }\end{array}$ & Mean & Min & Max & Sum \\
\hline $\begin{array}{l}\text { Kepemimpinan } \\
\text { transformasional } \\
\text { kepala sekolah }\end{array}$ & 65,5 & 56 & 73 & 11340 \\
\hline $\begin{array}{l}\text { Motivasi kerja } \\
\text { guru }\end{array}$ & 60.93 & 53 & 70 & 10480 \\
\hline $\begin{array}{l}\text { Kedisiplinan } \\
\text { guru }\end{array}$ & 33,45 & 23 & 40 & 5755 \\
\hline $\begin{array}{l}\text { Pengembangan } \\
\text { karir guru }\end{array}$ & 29.47 & 25 & 49 & 5078 \\
\hline
\end{tabular}

Selanjutnya data yang sudah terkumpul, dianalisa dengan analisis deskriptif dan analisis kuantitatif. Analisis deskriptif adalah merupakan suatu analisis yang menguraikan data hasil penelitian tanpa melakukan pengujian. Dalam analisis deskriptif secara ringkas akan dapat diketahui mean skor dari masing-masing variabel, median, modus, nilai skor maksimum maupun nilai minimumnya. Sedangkan analisis inferensial ditempuh dengan menggunakan alat analisis pengujian hipotesis dengan menggunakan uji signifikansi.

Kepemimpinan Transformasional Kepala Sekolah terhadap Pengembangan Karir Guru Sekolah Dasar

Kepemimpinan transformasional adalah sebuah proses di mana pimpinan dan para bawahan berusaha untuk mencapai tingkat moralitas dan motivasi yang lebih tinggi. Artinya pemimpin transformasional mencoba untuk membangun kesadaran para bawahannya dengan menyerukan cita-cita yang besar dan moralitas yang tinggi seperti kejayaan, kebersamaan, dan kemanusiaan. Kepemimpinan dengan gaya transforma sional mempengaruhi yang demikian, maka parameter yang digunakan dalam mengukur kepemimpinannya adalah dengan melihat dari tingkat kepercayaan, kepatuhan, kekaguman, kesetiaan, dan rasa hormat para pengikutnya. Sebab para pengikut kepemim pinan transformasional termotivasi untuk terus melakukan hal-hal yang lebih baik lagi untuk mencapai sasaran organisasi.

Berdasarkan hasil penelitian di Kecamatan Godean menunjukkan bahwa kepemimpinan transformasional kepala sekolah berpengaruh terhadap pengembangan karir guru, yaitu sebesar $18,1 \%$ satuan atau 0,181 yang berarti, apabila nilai kepemimpinan transforma sional kepala sekolah meningkat satu satuan, maka pengembangan karir guru meningkat sebesar 0,181 satuan. Hasil penelitian ini menunjukan besarnya pengaruh kepemimpinan transformasional kepala sekolah yang sangat tinggi terhadap pengembangan karir guru sekolah dasar.

Berdasarkan hasil pengolahan data penelitian dengan program SPSS 16 for windows menunjukkan besarnya Adjusted R_square adalah 0,181 yang lebih besar dari $\mathrm{R}$ tabel sebesar 0,138 pada taraf signifikansi $0,05 \%$. Hal ini berarti bahwa 
variabel kepemimpinan transformasional kepala sekolah berpengaruh signifikan terhadap pengembangan karir guru di Kecamatan Godean

Motivasi Kerja Guru terhadap Pengembangan Karir Guru Sekolah Dasar

Motivasi kerja adalah dorongan dari dalam diri dan dari luar diri seseorang, untuk melakukan atau tidak melakukan sesuatu yang terlihat dari demensi internal dan demensi eksternal. Motivasi kerja guru tidak lain adalah suatu proses yang dilakukan untuk menggerakkan guru agar perilaku mereka dapat diarahkan pada upaya-upaya yang nyata untuk mencapai tujuan yang telah ditetapkan. Atau dengan kata lain motivasi kerja guru memiliki dua demensi, yaitu: (1) demensi dorongan internal, dan (2) demensi dorongan eksternal.

Berdasarkan hasil penelitian di Kecamatan Godean menunjukkan bahwa, motivasi kerja guru berpengaruh terhadap pengembangan karir guru, yaitu sebesar 0,079 satuan atau sebesar 7,9\% yang berarti, apabila nilai motivasi kerja guru meningkat satu satuan, maka pengembang an karir guru meningkat sebesar 0,079 satuan.

Berdasarkan hasil pengolahan data penelitian dengan program SPSS 16 for windows menunjukkan besarnya adjus ted $\mathrm{R}_{\text {square }}$ adalah 0,079 yang lebih besar dari $\mathrm{R}$ tabel sebesar 0,138 pada taraf signifikansi $0,05 \%$. Hal ini berarti bahwa variabel motivasi kerja guru berpengaruh signifikan terhadap pengembangan karir guru di Kecamatan Godean.

Hasil penelitian ini memberikan makna bahwa faktor motivasi kerja guru memberikan sumbangan untuk pengembangan karir guru sebesar 7,9\%. Ini menunjuk kan bahwa motivasi kerja guru juga memili ki peranan dalam pengembangan karir guru. Walaupun besarnya pengaruh tidak sebesar faktor kepemimpinan transformasional kepa la sekolah. Motivasi kerja guru memberikan makna bahwa seorang guru untuk dapat mengembangkan karirnya ia harus memilki motivasi yang tinggi baik motivasi internal maupun eksternal.

Kedisiplinan Kerja Guru terhadap Pengembangan Karir Guru Sekolah Dasar

Disiplin Pegawai Disiplin Pegawai Negeri Sipil pengertian disiplin adalah kesanggupan pegawai negeri sipil untuk menaati kewajiban dan menghindari larangan yang ditentukan dalam perundangundangan dan/atau peraturan kedinasan yang apabila tidak ditaati atau dilanggar akan dijatuhi hukuman disiplin. Jadi setiap pelanggaran yang dilakukan oleh Pegawai Negeri Sipil ada sanksi atau hukumannya. Di dalam Peraturan Pemerintah disebutkan bahwa pelanggaran yang dilakukan oleh PNS dikategorikan menjadi 3 macam yaitu: pelanggaran ringan, pelanggaran sedang, dan pelanggaran berat. Sedangkan yang dimaksud dengan pelanggaran adalah setiap ucapan, tulisan, atau perbuatan yang tidak menaati kewajiban dan/atau melanggar larangan ketentuan disiplin PNS, baik yang dilakukan di dalam maupun di luar jam kerja. Sedangkan yang dimaksud dengan hukuman disiplin adalah hukuman yang dijatuhkan kepada PNS karena melanggar peraturan disiplin.

Berdasarkan hasil penelitian di Kecamatan Godean menunjukkan bahwa kedisiplinan guru berpengaruh terhadap pengembangan karir guru yaitu sebesar 0,082 satuan atau sebesar $8,2 \%$ yang berarti, apabila nilai kedisiplinan guru meningkat satu satuan, maka pengembangan karir guru meningkat sebesar 0,082 satuan.

Berdasarkan hasil pengolahan data penelitian dengan program SPSS 16 for windows menunjukkan besarnya adjusred R_square adalah 0,082 yang lebih besar dari $R$ tabel sebesar 0,138 pada taraf signifikansi $0,05 \%$. Hal ini berarti bahwa variabel kedisiplinan guru berpengaruh signifikan terhadap pengembangan karir guru di Kecamatan Godean.

Hasil penelitian ini memberikan makna bahwa pengembangan karir guru sekolah dasar juga dipengaruhi oleh kedisiplinan guru. Besarnya pengaruh kedi- 
siplinan guru sebesar 8,2\%. Hal ini memberikan makna bahwa kedisiplinan juga mempunyai peranan yang signifi kan. Besarnya pengaruh kedisiplinan guru mempunyai peranan yang lebih besar jika dibandingkan dengan dengan faktor motivasi kerja guru

Kepemimpinan transformasional Kepala Sekolah, Motivasi Kerja Guru, Kedisiplinan Guru terhadap Pengembangan Karir Guru Sekolah Dasar

Pengujian hipotesis ini memberikan bukti bahwa kepemimpinan transformasional kepala sekolah, motivasi kerja guru, dan kedisiplinan guru mempunyai arti yang sangat penting dalam pengembangan karir guru sekolah dasar di Kecamatan Godean. Hal ini bisa dilihat dari besarnya koefisien determinasi berganda sebesar 0,248 yang berarti 24,8\% dari pengembangan karir guru di Kecamatan Godean secara signifikan dipengaruhi oleh kepemimpinan transformasional kepala sekolah, motivasi kerja guru, dan kedisiplinan guru secara bersama-sama. Adanya kepemimpinan transformasional yang baik tidak mempunyai makna yang signifikan atau berarti bila tidak didukung oleh variabel yang lain misalnya motivasi kerja guru dan kedisiplinan kerja guru. Begitu juga motivasi kerja guru dan kedisiplinan guru tidak akan berarti secara signifikan apabila tidak didukung variabel kepemimpinan transformasional kepala sekolah. Dengan demikian keberadaan satu variabel tidak dapat berdiri sendiri dalam pengembangan karir guru tanpa didukung oleh variabel yang lain.

Hasil pengujian signifikansi pengaruh variabel kepemimpinan transformasional kepala sekolah, motivasi kerja guru dan kedisiplinan guru terhadap pengemba ngan karir guru di Kecamatan Godean, menunjukkan bahwa kepemimpinan trans formasional kepala sekolah ternyata memi liki pengaruh dominan terhadap pengembangan karir guru. Pengaruh dominan dari kepe mimpinan transformasional kepala sekolah ini ditunjukkan oleh besarnya oleh besarnya koefisien regresi kepemimpinan transforma sional kepala sekolah sebesar 0,181 lebih besar dari nilai nilai koefisien regresi motivasi kerja guru sebesar 0,079 dan nilai koefisien regresi kedisiplinan guru sebesar 0,082

Koefiensi regresi mengintepretasikan bahwa jika rata-rata skor kepemimpinan transformasional kepala sekolah, motivasi kerja guru, dan kedisiplinan guru meningkat satu satuan, maka akan berpengaruh terhadap kepemimpinan transformasional kepala sekolah sebesar 18,1\%, motivasi kerja guru sebesar $7,9 \%$ dan $8,2 \%$ dari kedisiplinan guru. Perubahan pengembangan karir guru yang diakibatkan oleh pengaruh kepemimpinan transformasional kepala sekolah terlihat lebih besar jika dibandingkan oleh perubahan yang diaki batkan oleh motivasi kerja guru dan kedisiplinan guru.

Dari ketiga variabel tersebut, variabel yang mempunyai pengaruh dominan terhadap pengembangan karir guru adalah kepemimpinan transformasional kepala sekolah. Hal ini disebabkan oleh karena mempu nyai pengaruh yang paling besar yaitu $18,1 \%$.

Berdasarkan tabel di atas pengolah an data penelitian dengan program SPSS 16 for windows menunjukkan besarnya adjusted $R_{\text {square }} 0,248$ yang lebih besar dari $\mathrm{R}$ tabel sebesar 0,138 pada taraf signifikansi $0,05 \%$. Hal ini berarti bahwa variabel kepemimpinan transformasional kepala sekolah, motivasi kerja guru dan kedisiplinan guru berpengaruh signifikan terhadap pengembangan karir guru di Kecamatan Godean.

Kepemimpinan transformasional kepala sekolah, motivasi kerja guru dan kedisiplinan guru secara bersama-sama berpengaruh signifikan terhadap pengembangan karir guru sebesar adjusted $\mathrm{R}_{\text {square }}$ $=0,248$ dengan konstanta 1.570. Ini berarti bahwa pengembangan karir guru di Kecamatan Godean Kabupaten Sleman sekitar $24,8 \%$ dipengaruhi oleh tiga variabel kepemimpinan transformasional kepala sekolah, motivasi kerja guru dan kedisiplinan 
guru. Sedangkan yang 75,2\% dipengaruhi oleh faktor yang lain.

Keterbatasan Penelitian.

Pengumpulan data yang dilakukan hanya menggunakan kuesioner yang diisi oleh guru dalam waktu yang relatif singkat, dan juga dasarkan pada pendapat guru yang memungkinkan sikap guru untuk berlaku keengganan, ketidakjujuran, kelelahan, dan tidak mengerti maksud pertanyaan dalam kuesioner.

Wilayah jangkauan responden yang hanya satu kecamatan, memungkinkan terjadinya hasil penelitian yang berbeda jika dibandingkan dengan wilayah kecamatan lain. Perbedaan ini mungkin disebabkan oleh karakteristik guru-guru di Kecamatan Godean yang memang mempunyai ciri khas tertentu di bandingkan dengan kecamatan lain di wilayah Kabupaten Sleman Daerah Istimewa Yogyakarta.

Penelitian ini hanya membahas tiga variabel yang berpengaruh terhadap pengembangan karir guru sekolah dasar di Kecamatan Godean. Dalam praktiknya di lapangan karir seorang guru sekolah dasar banyak faktor lain yang ikut menentukannya misalnya masa kerja, kompetensi paedagogik, kompetensi sosial, dan kemampuan berkomunikasi dengan orang lain.

\section{Simpulan dan saran}

\section{Simpulan}

Hasil penelitian berdasarkan perumusan masalah, tujuan dan hipotesis penelitian, dapat disimpulkan sebagai berikut. Kepemim pinan transformasional kepala sekolah berpe ngaruh secara signifikan terhadap pengem bangan karir guru sekolah dasar se Kecama tan Godean, Kabupaten Sleman, sebesar 18,1\%, dengan kontribusi koefisiensi determi nasi regresi sebesar 0,181 ( $p<0,05)$.

Motivasi kerja guru berpengaruh signifikan terhadap pengembangan karir guru sekolah dasar se-Kecamatan Godean, Kabupaten Sleman, sebesar 7,9\%, dengan kontribusi koefisiensi determinasi regresi sebesar $0,079(p<0,05)$.
Kedisiplinan guru berpengaruh signifikan terhadap pengembangan karir guru sekolah dasar se-Kecamatan Godean, Kabupaten Sleman, sebesar 8,4\% dengan kontribusi koefisiensi determinasi regresi sebesar $0,084(p<0,05)$.

Kepemimpinan transformasional kepala sekolah, motivasi kerja guru dan kedisiplinan guru secara bersama-sama mempunyai pengaruh yang signifikan terhadap pengemba ngan karir guru sekolah dasar se-Kecamatan Godean, Kabupaten Sleman, dibuktikan dengan koefisiensi determinasi regresi ganda 0,248 atau $24,8 \%$. dengan $\mathrm{F}=$ $19,955(\mathrm{p}<0,05)$.

Implikasi

Variabel kepemimpinan transformasional kepala sekolah mempunyai pengaruh yang dominan, maka seorang kepala sekolah harus dapat bertindak adil, arif, dan bijaksana dalam pengembangan karir bawahannya. Sebaliknya guru harus semakin meningkatkan ketaatan, dedikasi, kepatuhan, dan loyalitasnya terhadap kepala seko lah sebagai pimpinan di instansinya.

Motivasi kerja guru juga berpengaruh terhadap pengembangan karir guru yang membawa implikasi seorang guru harus selalu meningkatkan motivasi kerjanya. Seorang guru harus selalu semangat dalam menjalankan tugasnya baik ada atau tidak atasan di kantor tersebut. Seorang guru harus selalu memotivasi diri untuk selalu berprestasi dan dan meningkatkan kemampuan dirinya sendiri. Seorang guru harus selalu memanfaatkan waktunya untuk dapat menjaga motivasinya (semangat) dalam melaksanakan tugas sehari-hari.

Kedisiplinan juga berpengaruh terhadap pengembangan karir guru. Seorang kepala sekolah akan selalu mempertimbangkan faktor kedisiplian jika akan mengambil suatu keputusan yang menyangkut pengembangan karir bawahannya. Kedisiplinan ini dapat menyangkut aspek ketepatan waktu, kesesuaian tugas dan penyelesaian, dan juga disiplin dalam hal keuangan, yang pada intinya menuntut guru untuk selalu bertindak sesuai dengan aturan yang sudah berlaku. 
Saran

Analisis dan pengujian hipotesis membuktikan bahwa variabel kepemimpinan transformasional kepala sekolah mempunyai pengaruh dominan terhadap pengembangan karir guru sekolah dasar se-Kecamatan Godean. Oleh karena itu resiko pengembangan karir guru sangat ditentukan oleh kepemimpinan kepala sekolah. Hal tersebut membawa konsekuensi kepala sekolah harus dapat bertindak arif dan bijaksana terhadap bawahannya, sebaliknya guru juga harus selalu meningkatkan dedikasi, ketaatan, kesetiaan, kepatuhan terhadap kepala sekolah.

Motivasi kerja guru perlu diperlukan untuk meningkatkan peran terhadap pengembangan karir guru, maka kondisi motivasi kerja guru yang sudah baik ini perlu dipertahankan atau bahkan ditingkatkan dengan cara seperti membangun reward, pelaksanaan tugas, struktur-struktur kelom pok, dan pemberdayaan guru. Cara lain yang bisa digunakan adalah untuk meningkatkan motivasi kerja guru yang efektif adalah dengan cara memberikan penghargaan atau reward yang berbeda kepada guru sesuai dengan prestasi yang disumbangkan kepada sekolah.

Kedisiplinan kerja guru sekolah dasar di Kecamatan Godean perlu ditingkatkan dengan cara menerapkann aturan yang ketat sesuai dengan ketentuan yang berlaku. Penegakan disiplin hendaknya juga diikuti dengan perbedaan perlakuan kepada mereka yang tingkat kedisiplinannya tinggi tidak disamakan dengan mereka yang tingkat kedisiplinannya rendah. Penegakan disiplin hendaknya juga dimulai dari diri kita sendiri tidak dengan saling menyalahkan dan mencari kelemahan orang lain.

Kepemimpinan transformasional kepala sekolah, motivasi kerja guru, dan kedisiplinan guru berpengaruh terhadap pengembangan karir guru sekolah dasar se-kecamatan Godean, kabupaten Sleman, Daerah Istimewa Yogyakarta sebesar $24,8 \%$, hal ini berarti bahwa masih ada $75,2 \%$ pengaruh variabel lain yang ikut berpengaruh terhadap pengembangan karir guru. Berdasarkan hasil penelitian ini penulis sarankan kepada peneliti lain yang akan mengadakan penelitian tentang pengem bangan karir guru di wilayah yang sama, dapat memasukkan variabel lain yang secara teoritis berpengaruh terhadap pengembangan karir guru.

\section{Daftar Pustaka.}

Ardana, I. K., Mujiati, N. W., \& Utama, I. W. M. (2012). Manajemen sumber daya manusia. Yogyakarta: Graha Ilmu.

Arikunto,S. (2009). Manajemen Penelitian. Jakarta: PT. Rineka Cipta

Bass, B. M., \& Riggio, R. E. (2006). Transformational leadership. (2 $2^{\text {th }}$ ed). New Jersey: Lawrence Erlbaum Associaties. Inc.

Danim, S. (2008). Visi baru manajemen sekolah: Dari unit birokrasi ke lem baga akademik. Jakarta: Bumi Aksara.

(2012). Pengembangan profesi guru: Dari pra jabatan induksi, keprofesional madani. Jakarta: Kencana Prenada Media Group.

Flippo, E. B. (1976). Principles of personnel management. ( $4^{\text {th }}$ ed). Tokyo: McGraw Hill, Inc.

Gerungan, W. A . (2009). Psikologi sosial. Bandung: Refika Aditama.

Handoko, T. H. (1991). Manajemen persona lia dan sumber daya manusia. Yogyakarta: BPFE.

Hersey, P. \& Blanchard, K. (1732). Manage ment of organizational behavior: Utilizing human resour ces. ( $4^{\text {th }}$ ed). Englewood: Prentice Hall, inc..

Hoy, W. K. \& Miskel, C. G. (2008) . Educati onal administration: Theory, research and practice. ( $4^{\text {th }}$ ed). New York. McGraw Hill.

Ivancevich, J. M. (2010). Human resource management. (11 $11^{\text {th }}$ ed). New York: McGraw Hill. 
Malthis, R. L. \& Jackson, J. H. (2004). Human resource management: Manajemen sumber daya manusia. (alih bahasa Diana Angelica). Jakarta: Salemba Empat.

Mangkunegara, A. P. (2011). Manajemen sumber daya manusia perusahaan. Jakarta: Remaja Rosda Karya.

Mangkuprawira, Tb. S. (2003). Manajemen sumber daya manusia strategik. Jakarta: Ghalia Indonesia.

Mulyasa, E. (2004). Menjadi kepala sekolah profesional: Dalam kon teks menyuses kan MBS dan KBK. Bandung: Remaja Rosda Karya.

Nurtain. (1739). Supervisi pengajaran: Teori dan praktek. Jakarta: Depdikbud.
Nawawi, H. \& Martini, H. (1995). Kepemim pinan yang efektif. Yogyakarta: Gajah Mada University Press.

Nwaogu, G. U. (2014). Leadership in education. Atlantik International University http://www.aiu.edu/publications/student/english/131179/LE ADERSHIP-INEDUCATION.html. Diunduh 2 Januari 014

Pasolong, H. (2010). Kepemimpinan biro krasi. Bandung: Alfa Beta.

Permadi, D., \& Arifin, D. (2010). Kepemim pinan transformasional kepala sekolah dan komite sekolah. Bandung: Sarana Panca Karya Nusa.

Robbins, S. P. (1996). Perilaku organisasi: Konsep, kontraversi, aplikasi. (alih bahasa Hadyana Pujaatmaka). New Jersey: Prentice Hall, inc. 